\title{
Česká romská rodina v Anglii a zase zpátky - vymístěni
}

\author{
Kateřina Janků
}

\author{
SVĚT, V KTERÉM ŽIJI, BEZTAK VU゚BEC NENÍ \\ tak jako vše, s čím mám co do činění \\ - spoléhat jenom na svůj zrak - jak hloupé! \\ zrcadlo slepne, amalgam se loupe \\ a tak jak obraz můj v něm je jen zdáním \\ jsem přeludem i já, před ním i za ním... \\ J. H. Krchovský
}

Kdo zná básníka Krchovského, možná si klade otázku, jak souvisí dekadentův emocionální výlev s migrací českých Romů, nemluvě o vymístění. Je to právě ten zneklidňující pocit, že jsem přeludem, že přeludem je i svět, v němž žiji, a že přesto všechno jsem naživu. Být přeludem před i za zrcadlem, tento pocit může metaforicky vystihovat stav, kdy se jedinec ne a ne najít ve svém společenském odrazu, v reakcích okolí na svou přítomnost a své činy, a skrze to začíná pochybovat také sám o sobě - je vymístěn.

\section{Úvod - vymístění na dosah zkušenosti}

Vymístění jako separace člověka od jeho rodné kultury je podle Angeliky Bammer jednou ze základních formativních zkušeností 20. století (Bammer 1994). Termín „native culture“ pomáhá vystihnout povahu vymístění lépe, než český výraz „rodná kultura“, tak jak je tento výraz všeobecně chápán. Adjektivum ,rodná“ evokuje rodnou zem a ve zde používaném významu není do „rodné kultury“ zahrnuto pouze etno-kulturní prostředí národního státu, do nějž se člověk narodí. Jsou to spíše všechny kulturní a životně-stylové prvky, které tvoří prostředí primární socializace a stávají se tak samozřejmými a subjektivně reálnými (Berger, Luckmann 1999). V př́padě členů rodiny Balunovy, která bude průvodcem následujícího výkladu, je to u každého z nich osobitá kombinace prvků romské a české kultury, stejně jako životního stylu nižší střední třídy, životního stylu spjatého s dělnickými profesemi a v př́ípadě dětí manželů Balunových také s prostředím dlouhodobé nezaměstnanosti.

Hovoříme-li o vymístění na úrovni kulturních identit (Bammer 1994), je tedy potřeba brát v potaz všechny možné kulturní obsahy, které jedinec, považuje za jemu přirozené (přičemž může tyto představy sdílet s ostatními), respektive jedná v prirozené symbióze s nimi (čímž je samozřejmě zároveň reprodukuje). Vrátíme-li se ke Krchovského básnickému přímě-

Sociálni studia. Fakulta sociálních studií Masarykovy univerzity v Brně, 2/2004. S. 197-213. ISSN 1214-813X. Tento text vychází z výzkumu Migrace jako životní strategie marginalizovaných rodin, který v letech 2003-2004 finančně podpořila FSS MU Brno v rámci interního grantového projektu „MlaDěRo - Děti, mládež a rodina $\mathrm{v}$ transformaci“. 
ru, znamenala by nevymístěná existence na úrovni kulturních identit to, že se člověk poznává v zrcadle a připadá si na jeho obou stranách reálný, patřičný a zkonsolidovaný. Opakem jsou pak pocity nehmatatelnosti, nepatřičnosti a bezmoci. Samozřejmě, vymístění se neprojevuje jenom na úrovni osobních pocitů. Mưžeme je pozorovat skrze činnosti, at' již reflektované, či nereflektované, stejně jako skrze materiální statky a zacházení s nimi. Následující text pracuje s těmito třemi úrovněmi vymístění (pocity, činnosti a hmotný svět).

Vymístění, tedy separaci od rodné kultury, zakoušejí podle Bammer lidé v exilu - at' již dobrovolném (dobrovolné vyhnanství můžeme nazývat migrací), nebo nuceném, v exilu trvajícím rozmanitě dlouhou dobu, s rozmanitými právními statusy a s nimi souvisejícími společenskými postaveními - nebo jsou-li bez fyzické dislokace kolonizováni jinou kulturou. Kolonizace může ze sociologického hlediska nabývat právně a politicky rozmanitých uspořádání, které vždy charakterizuje dominantní, respektive hegemonní postavení jedné kultury (nazývané „majoritní‘) nad kulturami ostatními. Př́pad migrace českých Romů na západ v období existence samostatné demokratické České republiky v sobě obsahuje prvky obou forem vymístění. V jakém smyslu?

Čeští Romové jako vyhnanci. Od počátku devadesátých let se několik stovek romských rodin rozhodlo opustit Českou republiku a požádat o azyl ve vybraných vyspělých demokratických zemích. Tyto události mají dvě důležité makrospolečenské dimenze. Jedna se týká změn v politickém uspořádání po roce 1989 a vlivu těchto změn na azylové možnosti českých občanů, druhá se týká problematiky české státní př́islušnosti v souvislosti se vznikem samostatné České republiky v roce 1993 (Janků 2001).

Silné emoce, které odchod romských rodin stále vzbuzuje (zvláště v souvislosti s údajným poškozováním demokratické pověsti České republiky v zahraničí a s komplikacemi spojenými se znovuzavedením vízové povinnosti, respektive zpř́ísněním podmínek vstupu do některých zemí), kontrastují s poměrně nízkou informovaností o životních podmínkách romských emigrantů v cílových zemích, a konec konců i v jejich zemi domovské. ${ }^{1}$ Právě neinformovanost, respektive stereotypně selektivní informovanost, etnických Čechů o svých romských spoluobčanech je průvodním jevem kulturní hegemonie české etnické kultury v prostoru České republiky, která se v př́padě Romů vyznačuje prvky kulturní kolonizace.

Čeští Romové jako kolonizovaná kultura. V současné době zažívají mnozí Romové v České republice rasovou diskriminaci, ale jsou také komplexně společensky a kulturně znevýhodňováni. Komunistická ideologie bez-rozdílné společnosti zanechala i v této oblasti stopy svého působení. Dodnes si např́íklad mnoho Čechů myslí, že romština je dialekt češtiny, nebo jen soubor nesrozumitelných slangových výrazů podsvětí, přestože se jedná o svébytný jazyk podstatně odlišný od českého a slovenského jazyka. ${ }^{2}$ Podobné názory jsou běžné také co se týče romské kultury.

Hledání útočiště v cizí zemi lze vnímat nejen jako pokus o únik před rasovou diskriminací, ale také jako snahu o vymanění se z marginálního společenského postavení; jako únik ze života bez perspektivy plnohodnotného začlenění se do společnosti, ${ }^{3}$ respektive sociálního vzestupu, který není možný, v důsledku také díky etnické př́slušnosti. ${ }^{4}$

Cílem této stati je popsat dimenze kulturního vymístění, které můžeme pozorovat na př́padu rodiny českých Romů, která odešla v roce 2000 do Anglie a po několika měsících se 
vrátila zpět do České republiky. Pokusím se zodpovědět otázku, jak se kvalitativně proměnila situace Romů, kteří z České republiky odešli (a znovu se do ní vrátili), a to z hlediska vymístění jejich kulturní identity. Stat' si neklade za cíl přinést zobecnitelnou odpověd' na tuto otázku, odpovědí je spíše v osobní a společenské historii zakotvená analýza konkrétních činů konkrétních lidí.

Průvodcem na cestě poznání nám bude rodina Balunova. ${ }^{5}$ Po představení rodiny se zaměřím na vybrané významné vrstvy zkušenosti jednotlivých členů rodiny, které mají dohromady vytvořit konzistentní obraz kulturního vymístění. $V$ textu se střídají popisné etnografické pasáže s analytickými interpretacemi ve snaze zachovat věrnost rytmu života, tak jak jsem ho ve vyprávění Balunových zaznamenala, stejně jako přinést sociologicky inovativní pohled na zkoumané skutečnosti. Nezbytným doplňkem etnografické sociologie je také několik sebe-reflexivních autorských poznámek.

\section{Kdo jsou Balunovi - perspektiva etnografické sociologie}

Na Makovou ulici v Ústí nad Labem jsem zavítala několikrát v období prosinec 2003 - červen 2004. Manželé Balunovi a jejich školou povinní potomci, ${ }^{6}$ kteří zde bydlí, zkoušeli své štěstí v Anglii. Na začátku roku 2000 strávili pět a půl měsíce v Londýně. Poté se vrátili do svého bytu na Makovou. Zajímalo mě, v jakých podmínkách v Ústí nad Labem žijí, za jakých okolností odjeli do Anglie, za jakých okolností odjeli zpět do České republiky a jak hodnotí oni sami svou životní situaci v kontextu jejich zkušenosti, kterou má sociálně-vědný a politický diskurz ve zvyku nazývat „migrace“ (Lett 1990).

K Balunovým domů mě po předběžné dohodě přivedla sestra paní Moniky. S ní jsem se seznámila v komunitním centru, kde jsem hledala kontakty pro svi̊j výzkum. Od ní jsem se také dozvěděla, že do zahraničí odjel „po revoluci“ také jejich společný bratr. Nejsou jediní $\mathrm{v}$ rodině, kdo má zkušenost s migrací na západ. Po první společné návštěvě u Balunových mi sestra paní Moniky vyprávěla, že také bratr pana Baluno byl v Anglii.

\section{Z ničeho nic odjel.}

Toto stručné vyjádření dobře demonstruje častou zamlženost okolností odjezdu českých Romů na západ. Své sítě informací užívané při výjezdech do zahraničí si většina Romů chrání. Ani od pana Baluno a jeho manželky jsem se nedověděla mnoho detailů ohledně předodjezdových př́íprav jejich cesty. ${ }^{7}$ Paní Balunová letěla se třemi dcerami napřed. Později přiletěl pan Baluno se synem. Úřady pomohly rodině dát se v Londýně dohromady, s vyřizováním dokladů pomáhal také kamarád pana Baluno, kterého $\mathrm{v}$ Londýně potkal a který už byl v době jejich př́chodu nějakou dobu na místě. Po pár týdnech, když už si děti pomalu zvykaly a manželé získali dobře placenou př́ležitostnou práci, rozhodl se pan Baluno, že požádá o deportaci. Jeho otec vážně onemocněl a on si nedovedl představit, že by mu v takové chvíli nebyl nablízku.

\section{Co je zde možné hledat a nalézł}

Abychom mohli blíže prozkoumat projevy vymístění v životní etapě rodiny Balunovy, která zahrnuje zkušenost emigrace a re-emigrace, je potřeba nějakým způsobem uchopit její 
životní podmínky. K popsání životních podmínek Balunových nám dopomůže koncept kvality života, který se obecně týká míry, do jaké je život lidí dobrý nebo uspokojující (Szalai 1980). Důležité je, že tento koncept se používá pro usuzování o skupinách lidí spíše než o jednotlivcích a v tomto smyslu odráží skrze výpovědi jedinců širší společenské vztahy.

Pozoruhodná je také jeho singularita: jak poznamenává Szalai, v sociálních vědách se zř́́dka hovoří o kvalitách života, respektive kvalitě životů (Szalai 1980: 9). V tomto smyslu následuje koncept kvality života stratifikační společenskou logiku. Lidé, kteří uvažují o kvalitě svého života, jsou na tom v rámci definované společnosti různě, ale poměřují se navzájem mezi sebou a mají ponětí o tom, jak by to vypadalo, kdyby se měli lépe, respektive hưře, vzhledem ke zvolenému referenčními rámci.

Koncept kvality života je používán rozmanitým způsobem, proto je vždy potřeba ho blíže vymezit. Bourdieovým jazykem řečeno, „statky“ a „aktivity“ jsou zde prezentovány jako materiální podmínky a sociální podmínky. Přeneseně je také možno říci, že materiální a sociální podmínky obsahují ekonomický, sociální a symbolický kapitál, přičemž symbolický kapitál se potenciálně realizuje skrze oba předchozí kapitály.

Výzkumy kvality života kombinují „objektivně měřitelné“ charakteristiky (jako je celkový př́ijem domácnosti) se subjektivními hodnoceními životních podmínek a toto rozlišení zachovávám i já. Celkově pak schéma kvality života vypadá následovně:

OBRÁZEK 1. Kvalita života

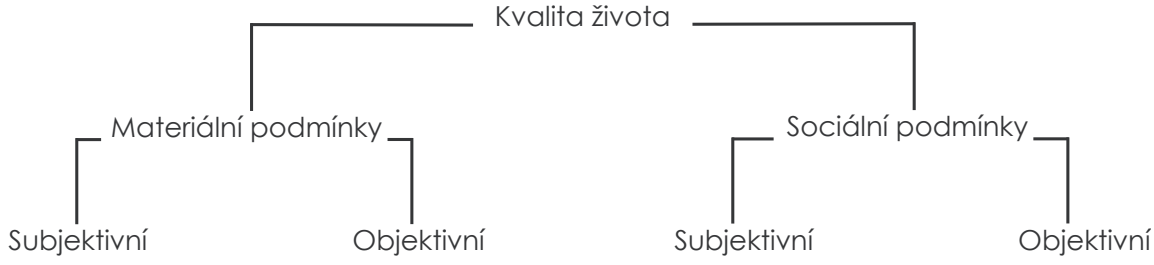

Objektivně měřitelné charakteristiky ${ }^{9}$ se v kontextu prezentovaného výzkumu prolínají se subjektivním hodnocením a verbalizovanou reflexí a není proto nutné ani chtěné subjektivní charakteristiky od objektivních výrazně oddělovat. Je však dobré mít existenci těchto dvou rozměrů na zřeteli.

Materiální a sociální podmínky života přibližím čtenáři v optice duality domov-pracoviště na príkladu toho, jak Balunovi bydlí a bydleli ve třech časo-prostorových oddílech své zkušenosti a jak hovořili o své zkušenosti zaměstnání.

Domov jako protiváha pracoviště, to je podle Parsonse jedno ze základních dělení charakterizující moderní společenskou strukturu. Domov a pracoviště si navzájem dodávají význam. Jejich vymezení bývá nejen prostorové, ale i časové. „Jít do práce“ většinou znamená fyzicky se přemístit z jedné lokality do druhé, ${ }^{10}$ jinak se obléct, připravit se na jiný typ komunikace a sebeprezentace. V moderní společnosti se má za to, že, narozdíl od zaměstnání, doma je člověk autentický. Sibley dokonce mluví o domově jako o metafoře ráje (Sibley 1995). „Chození do práce“ je pak mnohem širší pojem než „,vydělávání peněz potřebných 
pro zajištění soukromé existence“, a naopak. Na sféru zaměstnání se metaforicky váže jakési společensky funkční předstírání, přizpůsobování se celku a společná produkce kolektivně prospěšných statků. ${ }^{11}$

Třetím představeným rozměrem života Balunových budou jejich vzorce spotřeby, nebot' spotřeba je jednou ze základních pozdně moderních zkušeností (Slater 1997) a dobře ukazuje životní podmínky včetně přání a preferencí aktérů.

\section{Domov - kdo židli má, bydlí}

Manželé Balunovi s dětmi bydlí ve čtvrti, jejíž jméno se etnicky českým Ústečanům asociuje s Romy, rozhodně by ji však necharakterizovalo označení ghetto. Je zde hlavní vlakové nádraží, mnoho měšt’anských domů z 19. století dostalo v posledních letech novou fasádu. Najdeme zde i panelové domy, v jednom z nich žije sestra paní Balunové s rodinou. Vzezření a pověst ulice Makové, na které Balunovi bydlí, však stereotyp romské čtvrti v negativním smyslu slova (špinavá, nebezpečná, žijící svým hlučným a kriminálním způsobem) v něčem podporuje. Když jsem jedno letní dopoledne jela k Balunovým na kole, na rohu jsem zastihla mladého chlapce $\mathrm{s}$ igelitovým sáčkem naplněným těkavou látkou u obličeje. Takto otevřeně fetujícího mladého Roma jsem bohužel v Ústí nad Labem neviděla poprvé. Uvědomila jsem si také, že kdybych zde neměla známé, těžko bych na ulici zavítala. Ne ze strachu, spíše z nezájmu a ostražitosti. V blízkosti také není žádné společenské zařízení, kromě bývalého rockového klubu, v němž je nyní komunitní centrum na pomoc drogově závislým. Balunovi bydlí v činžovním domě, který nebyl několik desetiletí zevrubně opravován, ale v dezolátním stavu není. Dvůr je neuklizený, chodba umytá, ale oprýskaná. Když jsem přijela na kole a chtěla si ho zamknout nahoře přede dveřmi, řekla mi paní Balunová, at’ si ho klidně nechám na chodbě nezamčené, že tady mi ho nikdo neukradne. Kolo na chodbě vyprovokovalo jen několik zazvonění od kolemjdoucích sousedů, kteří byli zvědaví, kdo k Balunovým na kole přijel. Zdálo se, že pro toho, kdo je tady doma, to může být docela př́ijemné a bezpečné bydlení (botník s botami byl rovněž na chodbě). Balunovi mají dvoupokojový cihlový byt s průchozí koupelnou, samostatným záchodem, velkou kuchyní a balkonem. Zařízení je skromné, nicméně nechybí nábytková stěna s vystaveným sklem, velká sedačka; peřiny se stelou do rohu na zem, na skř́ń na peřiny nejspíš nezbyly peníze ani prostor. Je to tentýž byt, v němž žili, než odjeli do Anglie. Protože se má všeobecně za to, že čeští Romové získávají prostředky na cestu do zahraničí tím, že takzvaně „,všechno prodají“, to znamená zpeněží vybavení domácnosti i samotný byt, zeptala jsem se na to.

KJ: Jak jste se prripravovali na cestu? Prodali jste věci?

MB: Nic jsme neprodali, tchýně nám platila byt, tchýni mám dobrou. Všichni přišli. První každý přijel, brácha nám záviděl, že jedem $[\ldots]^{12}$. Kupovali nám věci na cestu, abysme měli.

Z uvedené citace se nedá jednoznačně usuzovat, zda se Balunovi plánovali z Anglie vrátit. Spíše měli jako širší rodina prostř̌edky udržet byt rok či dva v pohotovosti, kdyby se Balunovým v zahraničí nedařilo, aby se vyhnuli skokovému zchudnutí rodiny, která by se vrátila do Ústí bez peněz a neměla by ani kde bydlet (jak se to některým rodinám stalo). Je 
dost možné, že postupem času, kdyby v Anglii zakotvili, by Balunovi přijeli do Ústí urovnat majetkové poměry a prodali by dekret na byt, nebo by naopak koupili podíl v nově vznikajícím bytovém družstvu, anebo by byt přenechali někomu z rodiny.

Manželé Balunovi s dětmi bydleli v Anglii celkem na třech místech. První z nich byl hotel Rab. Ubytovna pro nově příchozí žadatele o azyl není př́mo placená klienty a Balunovi v ní byli dva nebo tři dny. Protože paní Balunová s dcerami přijela do Anglie o týden dř́ve než pan Baluno se synem, setkali se až v dalším hotelu, kam pana Baluno po třech dnech pobytu v hotelu Rab po souhlasu manželky (který si vyžádaly britské úřady) přijel. Z druhého hotelu se Balunovi přestěhovali do cihlového domku, který sdíleli s Romy s Rumunska a tam strávili většinu z pěti a půl měsíců svého pobytu v Londýně.

Paní Balunová vzpomíná na hotel Rab, který nazval pan Baluno „takovou rozdělovnou“, jako na špinavé a denervující místo prvních dní v Londýně, které pro ni byly už tak psychicky náročné.

MB: Já jsem tam jela s děckama, no tam jsme dostali takový formulár̆, lísteček, jako že jsme emigranti, všechno. Na letišti nás dali dál, tam byli i jiní cestující, čekali jsme tam dvě, tři, čtyři hodiny, každá hodina byla jak věčnost. Děcka byly unavené, špinavé byly. [...] Měla jsem obavy, co s nama bude. Pak nás zavezli do takového kumbálku, kde nám dali jídlo a pití, take mince bezplatně do automatu, kde jsem mohla děckám koupit balíček brambůrků, kolu, sodovku a sendvič. No a čekali jsme. Nebyli jsme sami, museli jsme čekat na českého interpreta. Pak jsme šli na takovou běžnou prohlídku, srdce, jestli něco nemáme, dívali se do pusy, brali nám otisky prstů, to byl šok. Pak jsme vyplňovali ty papíry, byla tam ta interpretka, tak to s nama dělala. Pak že půjdeme, ty papíry jsme dostali do takové složky, interpretka odešla a ted’ jsme tam zůstali. Dali nás na autobus, že nás odvezou. Bála jsem se, neměla jsem peníze, bylo to hodně věcí, měli jsme strach, neměli jsme jízdenku, bylo to domluvené s řidičem. Jeli jsme dvě hodiny v kuse, děcka usínaly. Konečně jsme vystupovali, bylo to na hlavním letišti, tam jsem jim podala ten papír, co mi dal, řekl at’ počkám, tak nějak jsem to z toho jak se tváŕil vycítila. Čekali jsme, chtěli dokumenty, myslela jsem, že chcou pasy, myslela jsem, že nám je chcou zebrat, že nás pošlou domů, nechtěla jsem jí je dát. Nechali nás čekat, v takovém kumbálu s Rumunama, trošku jsem se s nima domluvila, bo jsem se učila ruštinu. Věrka už chtěla spát, Aneta chtěla spát, ted' jsme měli tašky, pomohli nám s něma do takového malého autobusu, takové velké auto to bylo. Ten hotel,

\section{KB: Hotel Rab.}

MB: Rab? No, byl dost špinavý. Dali mi klíče a pokoj jsem si měla najít sama.

KB: Číslo šedesát devět jsme měli.

MB: No a měli jsme největší pokoj, bylo to v př́zemí, tak jsem měla strach, sama na jedné chodbě, bez chlapa, tak jsem zavřela, zatarasila jsem dveře, byla jsem neklidná a hned jsme lehli. Ráno jsem se podívala po pokoji a byla jsem úplně hotová, kde to jsme. Koupelna byla společná, záchody byly společné, na klíčích byla taková tabulka, kde bylo napsané, že snídaně je sedm čtyřicet, oběd ve dvanáct večeře $v$ šes [jazyková zvláštnost paní Balunové], ted' jsme nevěděli, kde je jídelna, nic, nahoře vydávala taková černoška jídla,

\section{KB: Furt byly vajíčka.}

MB: tam jsme byli tři dny a pořád samé jídla, kde byly vajíčka, pečený chleba, máslo, více druhů, ted' jsme se neuměli domluvit, no hlavně, že se děcka najedly. Ted' oni nám dali třeba filety a rýži, ted' já jsem byla z toho na nervy, nemohla jsem se domluvit. Pořád bylo to samé jídlo, moje děcka dělaly [...], mi bylo hrozně, nespala jsem, nebylo to dobré. 
Po třech dnech zavezli paní Balunovou s dcerami do druhého hotelu. Životní podmínky v něm hodnotila jako lepší, také již byla odpočinutější po namáhavé cestě, a tak začala s dcerami pracovat na rekonstrukci „,normálního života“, ke kterému patří domácí jídlo, čistá kuchyn̆ a dobrá káva.

MB: Bydleli jsme $\mathrm{v}$ hotelu v druhém patře, hotel byl čistý, krásný, dostali jsme klíče, byla tam na zavírání koupelna, umyvadlo v pokoji, společný záchod, byli tam Rumuni, ti měli dva pokoje, jeden černoch, ten tam měl práci, já jsem měla jenom jeden pokoj. Byla tam televize, jedna skř́ňn a samé postele.

\section{KB: Dvě postele.}

MB: A měli jsme tam stůl a židli. No a na druhý den na snídani, to jsem měla dost. To byla děsná snídaně. Ted' mi došly cigarety, ted' jsme nevěděli, kde jsou obchody, jeden byl za rohem, tak jsem tam zašla a koupila jsem děckám banán, jogurt, marmeládu a ted' jsem hledala cestu zpátky a ty baráky jsou všechny stejné. Adresu jsem měla v kapse, ale nemohla jsem najít cestu, věděla jsem, že je to kousek, tam bylo více baráků červených, pak zastavil v autě takový černoch, sportovec, a ukazoval mi, kde to je, ale já jsem mu nevěřila, že má pravdu. Ale on popojel autem, když viděl, že jdu jinam a furt mi ukazoval tam. Tak jsem ho poslechla a našla jsem to. Byli jsme hladoví, vyčerpaní a štastní. Po snídani nebylo nic, tak jsem udělala svačinu, neměla jsem kávu, tak jsem byla úplně hotová. Já jsem bez kávy úplně hotová. Tam byl ten zaměstnanec, on mi udělal kávu, ale to byla taková jiná, ne dobrá, tak jsem před ním tu kávu vylila, už jsem z toho byla na nervy, už to na mě bylo i vidět. Seděli jsme dole v křesle celý den, bála jsem se ven, že zas zabloudím. Ten zaměstnanec nás chválil, ostatní děcka něco udělaly a Kája to šla povysávat. Já jsem brečela, s Rumunama jsme se domluvili, ukázali mi cestu do obchodu, ted' jsem nevěděla ceny, částku jsem u pokladny nerozuměla, tak jsem tak [ukazuje dlaň] dávala peníze a oni si sami brali [negativní emoce]. Ovoce jsem tam kupovala, tam byly takové stánky, tam jsem koupila pomeranče a banány, dal mi k tomu zadarmo citrón. Pak jsem šla k děckám domů, neměla jsem hrnec, půjčila jsem si od manažera, taky sůl, př́bory jsem musela vyžebrat a uvařila jsem děckám první jídlo, rýži a maso $s$ hráškem. Nejdřív jsem ale uklidila kuchyň, tam byly jenom také dvě plotýnky a každý tam vařil, tak tam byla špína. Tak jsme byli najezení a já bych si dala kávu, už jsem z toho byla na nervy. Ted' jsem nevěděla v obchodě, jaká je ta naše normální káva, šla jsem za jedním a ten mi půjčil kávu, tak jsem se uklidnila. Tak jsme seděli na pokoji. Pak volali, že přijel manžel se synem a jestli chcu, aby přijel, jestli může přijet, tak jsem ř́ikala, že jo.

Poté, co se rodina dala dohromady, britské úřady jí s pomocí polského překladatele pomohly najít bydlení.

LB: Pak jsme bydleli v takovém cihlovém domečku, okolo bylo všechno stejné, tam jsem se cítil super $[\ldots]$ bylo to sice kus od školy, ale bus jezdil od baráku, byla to indická čtvrt'.

Paní Balunová vzpomíná na bydlení v cihlovém domku především v souvislosti s obtíživým soužitím se sousedy a s traumatizujícími podmínkami života kvůli myším, které nebyl správce domu hned ochoten $\mathrm{z}$ domu odstranit.

MB: Dostali jsme barák, který jsme měli rozdělený s Rumunama, to je nejhorší národ, ti rumunští cigáni tam chodili žebrat, tak dělali špatnou reputaci i pro nás, lidi si mysleli, že patří k nám a pak se s nama nechtěli bavit. Oni byli početná rodina, v dvoupokojovém bytě bylo dvacet lidí, děcka byly nepořádné, zabrali si pro sebe dvorek, ted' tam byly krysy, take velke, a oni jim normálně dávali jídla, jsem ju viděla, jak normálně tu krysu krmí. Ted’ jsem pověsila prádlo, na takové dřevo za bará- 
kem, ted' věším a vedle mě krysa, tak jsem měla šok. Ted' na záchodě jsme měli myši. Já se bojím takových zvírat, všeho, co leze, a ted' jsem je měla normálně doma. Já jsem to šla hlásit správci, to byl takový Ind a on že mi nerozumí, ale rozuměl mi moc dobře. Chodili jsme na sociálku a moc nám pomoh ten advokát, pomoh nám to vyřídit. Dyt' jsme před něma neměli kam utéct, a bydlet $\mathrm{s}$ myšma, já jsem nemohla spát, dali jsme hadry dovnitř, do těch děr a ony si tam normálně hrály, já jsem nemohla celou noc spát, děcka měly panickou hrůzu, ted' já jsem nespala celou noc, jeho sem budila, ten byl ze mě na nervy. Nechtěla jsem chodit ven, aby nebyly v bytě. Advokát přišel ještě $\mathrm{s}$ jedním, ukázal mu byt, řekl OK a bylo to zařízené, manažer to zařídil. Říkali jsme na sociálce, že na to nejsme zvyklí, tak tam dali nějaký jed, take krabičky, ale to nefungovalo, no já jsem měla úplně šok, zašla jsem na sociálku, že tam nebudu bydlet, že to neexistuje. Manažer se o to nestaral, aby neztratili velké peníze, pak přinesl takový př́stroj do zásuvky, co dělal zvuk, který my jsme neslyšeli, ale ty myši už jsme tam pak neměli.

\section{Vymístěný domov - provizorium a ostražitost}

Domov - tato Sibleyovská metafora ráje, prostor, kde má být moderní člověk autentický, je zároveň prostorem, kde se separace od rodné kultury může dobře zviditelnit.

Společná koupelna v azylové ubytovně znamená pro paní Balunovou narušení soukromí a toto narušení soukromí přináší narušení života podle vlastních představ, podle představ o dodržování hranic mezi lidmi, ale také představ o hygienickém standardu domácnosti. To se ostatně prolíná celým vyprávěním o Anglii (nepořádek v domě, ve kterém bydleli s rumunskými Romy, uklízení společné kuchyně v hotelu, než se paní Balunová dala do vaření).

Vzhledem k předpokládaným životním prioritám paní Balunové (nejdříve zabezpečené, tedy oblečené a najezené děti, uklizená domácnost, a potom vše ostatní), znamenala emigrace do Anglie v prvních dnech narušení možnosti hladce obstarat základní potřeby rodiny. Nádobí si musela paní Balunová půjčit, koupelna a kuchyň byla uživána jinými obyvateli ubytoven a tudíž nemohla mít kontrolu nad jejich stavem. Stejně jako rodina prakticky neměla kontrolu nad tím, kde a s kým bude bydlet, a záleželo tedy jen na náhodě, jestli se přidělené ubytování bude blížit, nebo vzdalovat jejich představě o spokojeném bydlení.

Pocit, že zabezpečení základních funkcí spojených s domovem je ohroženo, může přerůstat ve všeobecný pocit ohrožení, strachu. Strachu z budoucnosti, strachu o vlastní bezpečí, když muž není př́tomen, strachu z myší, které se navzdory protestům adresovaným správci objektu stále v domácnosti objevují.

Eliminace pocitů ohrožení je pak ztěžována dezorientací v novém prostředí. Lidé hovoří jiným jazykem (což také znamená, že mohou předstírat, že nerozumí stížnostem a žádostem), ulice jsou neznámé, orientační body matoucí. Ve stavu dezorientace pak člověk snáze nedůveřuje svému okolí, a to je již od metaforického ráje domova Davida Sibleyho hodně vzdáleno.

Jednu věc sdílí povaha domova Balunových v Ústí nad Labem i v Anglii. Je to pověst čtvrti, ve které bydlí. Indická čtvrt' v Londýně nejspíš nebude vyhlášenou prestižní adresou, a tak se dá předpokládat, že se členové rodiny opět ocitli v chudinské oblasti s omezenými možnostmi sociálního vzestupu. To nemusí znamenat, že se na daných místech kvưli těmto omezeným možnostem necítí dobře nebo doma. Lokalita, kde Balunovi bydlí (a bydleli v Anglii) je však lokalitou, kde se odehrávají všednodenní př́běhy ze života na okraji společnosti. 


\section{Zaměstnání - druhý pól moderního života}

Balunovi získávají peníze $\mathrm{v}$ zásadě třemi způsoby: placenou prací; pobíráním podpory v nezaměstnanosti nebo sociálních dávek; posledním zdrojem, který se v průběhu výzkumu vyjevil, je finanční a materiální podpora širší rodiny Balunových. ${ }^{13}$

V současné době získávají Balunovi finance především ze sociální podpory. Ani jeden $\mathrm{z}$ manželů nepracuje, děti ještě nejsou zletilé. Když jsem u nich byla naposledy v červnu 2004, paní Balunová mi s obavami sdělovala, že manžel právě zkouší pracovat načerno jako závozník na stavbě a že ho hned první den přistihla policie, což potvrdilo její varování, aby to nedělal.

Co se týče získávání peněz skrze systém sociálního zabezpečení v Anglii, „sociálka“ znamená ve vyprávění Balunových zažehnání základní existenční nejistoty v cizí zemi a zabezpečení základních potřeb.

MB: Jídlo je jiné, ale bylo to dobré, dostávali jsme peníze týdně a dalo se $\mathrm{z}$ toho vyžít.

Nyní se věnujme zkušenosti Balunových s placenou prací. ${ }^{14}$ První zmínka o zaměstnání Balunových z období před migrací se týká restrukturalizace ekonomiky v procesu přechodu na hospodářství volného trhu v devadesátých letech dvacátého století.

LB: Já jsem pracoval ve firmě, cigány propouštěli, vesměs cigány.

$\mathrm{S}$ etnicky/rasově orientovanými překážkami v př́istupu k zaměstnání se Balunovi setkali i v Anglii. Tam ovšem práci získali, díky svému osobnímu vkladu.

LB: Ale já budu jezdit za prací.

KJ: Jo?

LB: No. Já jsem tam i pracoval.

KJ: Aha.

$[\ldots]$

LB: No, tam v baráku, ${ }^{15}$ to bylo solidní. Př́mo v baráku. Uklízel jsem listí, sekal jsem, pálil, z toho byl dým. Bylo parno, nemoh sem to vydržet, nadával jsem, tak jsem se šel zeptat na práci. Oni věděli, že nejsme ti Rumuni, brali nás, jako rodinu, že s Rumunama nic nechceme mít, viděli, že jsme čistí, že se jinak chováme.

MB: Vzali ho na zkoušku na úklid baráku, no a já jsem měla uvařené, poklizené, děcka byly v pořád$\mathrm{ku}$, tak jsem mu šla pomáhat.

KJ: Jak dlouho jste tam pracovali?

LB: Týden.

KJ: Týden?

MB: Pak jsme požádali o deport.

LB: Denně mi dával padesát liber. A cigarety také fajne, černé se zlatým proužkem. 
MB: Teodora vzal k sobě na oběd domů. Měl tam starou matku, tak jsem mu pomáhala se o ní starat.

LB: Odvážel jsem smetí, děckám dal třešně ze zahrady, televizu.

MB: Kdybysme zůstali, měli bysme se dobře. Já bych dělala ošetřovatelku, on by též furt měl práce. Pracovní doba byla jak my jsme chtěli.

LB: Pracovali jsme tak od šesti do sedmi večer. Jak jsme si usmysleli, jak nám to vyšlo, tak jsme šli pomáhat. Neměli jsme nějaké závazky, pomáhal jsem na zahradě, chválil nás, že jsme pracovití. Když to viděli Rumuni, tak se nahrnuli přes plot, ale on jim řekl, že je do práce nebere. Říkal mi Mistr Baluno.

MB: A mi ř́íkal Miss, ne Lady Balunová. Lady Balunová [Paní Balunová se hezky usměje].

Na závěr ještě jedna obecná zmínka o vztahu Balunových k penězům. Je důležitá zvláště v kontextu debat soustřed'ujících se na to, zda je „romská migrace“ ekonomickou migrací, nebo ne. Perspektiva etnografické sociologie pomáhá objasnit, že takto položená otázka př́iliš nesměřuje k poznání motivací a okolností vedoucích k migraci samotných českých Romů. V první reprodukované pasáži vzpomíná paní Balunová na rozhovor s jejich právníkem, se kterým se sblížili a který se poté, co mu oznámili, že žádají o deport, snažil Balunovy přesvědčit, aby z Anglie neodjížděli, a chtěl k tomu nějakým způsobem přispět, a tak hledal, co by pro ně mohl udělat.

MB: Nechtěl, abysme odjeli. Říkala jsem mu, že jsme nespokojení s bytem, říkal, že nám pomůže, abysme měli dobré podmínky, že se budeme mít dobře, trval na svém, Robert [právník] to nemohl překonat. Říkali jsme, že nám nejde o peníze. Dal nám čas na rozmyšlenou.

Hybným momentem návratu do Ústí nad Labem bylo onemocnění otce pana Baluno, ale rozhodnutí odjet se poskládalo z více okolností, jako byly neuspokojivé bytové podmínky, či nemoc jedné z dcer. $\mathrm{V}$ tomto smyslu nemohla Balunovy v Anglii pravděpodobně udržet jakkoliv výhodná nabídka. Neznamená to však, že by na peníze při rozhodování nebrali ohled. Druhá reprodukovaná pasáž se váže na zpětné hodnocení života v Anglii a př́ípadné budoucí plány na re-emigraci. ${ }^{16}$ Ukazuje naopak, že peníze roli při rozhodování o migraci hrají.

LB: Všude dobře, ale doma je doma. Já už bych nejel nikde.

MB: Angličani jsou divní, Indové, jsou čistí, ale chovají se k sobě solidně, na veřejnosti vás pozdraví, ukloní se, Pákistánci, mají úplně jiné chování, oblečení. Angličani, to je ošumpatělý národ, ženské tam nosí ty baganče, výchova je tam jiná, je tam zákaz bít děcka, můžou dělat kravál, můžou skákat. Zas ty peníze.

Tato pasáž zároveň ukazuje, jak jsou úvahy o penězích přirozeně zapleteny do jiných aspektů kvality života. Vedle toho poukazuje na existenci protikladů ve schématech každodenního života, což právě staví hypotézy o tom, zda je „romská“ migrace migrací ekonomickou, nebo nikoliv, do světla irelevantnosti, respektive nízké poznávací hodnoty takto položené otázky. 


\section{Vymístěné zaměstnání - zranitelné výdělky}

Balunovi si přímo na nedostatek peněz nestěžovali, ale z jejich životních podmínek je celkem zřejmý. Také v Anglii žili, zvláště zpočátku, ze základních finančních prostředků získaných skrze systém sociálního zabezpečení. V exilu byl nedostatek peněz o to více stresující, že se rodina mohla méně spoléhat na nefinanční zdroje, jako je pomoc př́buzenstva či nákup v nejlevnějším známém obchodě. Dezorientace v zacházení s penězi umocňuje strach z nové situace.

Podobně jako v př́ipadě domova, také v oblasti zaměstnání jsou patrné podobnosti životních podmínek na obou místech. Práci, kterou pan Baluno, případně jeho manželka, dovede získat, je prací nejistou, nárazovou a nelegální. Neskýtá tedy patřičné sociální jistoty pravidelného př́ijmu a jakkoliv si zaměstnání v Anglii Balunovi chválili, je otázkou, zda by byl takový výdělek dlouhodobě jistý a uspokojivý. Pravdou je, že v České republice se k nepravidelnosti práce přidává významný faktor rasové diskriminace. Zde má pan Baluno jen malou šanci přesvědčit zaměstnavatele o své pracovitosti, protože práci jednoduše nedostane. Vzhledem k tomu, že jsou oba manželé již několik měsíců prakticky nezaměstnaní, zvyšuje se také riziko snižující se schopnosti do práce pravidelně chodit, což zvyšuje pravděpodobnost uvíznutí na společenském okraji. V tomto smyslu nelegální nárazová práce v Anglii poskytuje optimističtější vyhlídky, než stejné pracovní př́ležitosti v České republice, a to jednak z důvodu výdělku v silné měně a jednak proto, že v Anglii se manželé setkali s otevřenou šancí prokázat se coby dobří pracovníci.

\section{Spotřeba - povinný doplněk životního zpưsobu v pozdní moderně}

Balunovi se nezmiňovali o tom, že by kdy uspořili nějaké peníze. Spíše mluvili o možnostech, jak ušetřit při nakupování, nebo co by si rádi dovolili a nemohou. Spotřební vzorce Balunových jsou významně určeny velikostí domácnosti a životními fázemi jejích jednotlivých členů. Balunovi jsou ve středním věku, neuvažují o tom, mít další dítě (alespoň o tom nemluvili), a mají čtyři děti v rozmezí 9 až 17 let věku. Při př́ijezdu do Anglie to např́klad znamenalo zvážit poměrně velkou investici za oblečení, vzhledem k neočekávané změně počasí.

KB: A horko tam bylo.

MB: Ted' my jsme měli normálně zimní věci a tam už bylo teplo v březnu, tak jsme měli problém $\mathrm{s}$ věcma.

Materiální zaopatření dětí je zdá se pro paní Balunovou velmi důležité. Hodnotila celkovou úroveň Angličanů ve světle své představy, jak je potřeba starat se o děti.

MB: Jinak Angličani mi přršli takoví zaostalí, v únoru chodily děcka bez ponožek...

Ve srovnání s Anglií si paní Balunová stěžuje na současnou nemožnost konzumně-společenského vyžití oproti tomu, jakého rodina užívala v Anglii.

MB: Chodili jsme s děckama na kolotoče, tady nemůžem jít na kolotoče, nemůžeme si to dovolit. Tam jsme chodili do KFC normálně, děcka na to byly zvyklé, tady si to nemůžu dovolit, tam jsme si 
dávali ty velké porce, tady je to strašně drahé, když jste na podpoře. Tady děcka neznají McDonald. Tam znali. Tady si to nedovolíš [k sestře].

Vzorce spotřeby nezahrnují jen kalkulaci potřeb a možností jejich materiálního uspokojení. Jsou také otázkou zvyku.

MB: Mám pocit, že už jsme si zvykli zase tady. Na ceny, vaření, jídlo je jiné.

V hierarchii spotřeby jednoznačně dominuje jídlo (nejen množstvím zmínek, ale také jejich umístěním - objevovaly se na počátku vyprávění o zabydlování se v Anglii).

Jídlo v pozici základní potřeby však není pouze „vnucováno“ systémem sociálního zabezpečení.

MB: Byli jsme na sociálce, [...] dostali jsme první peníze, tak jsme byli celí št’astní. Šli jsme do levného obchodu, to Tesco, a nakoupila jsem děckám a uvařila jsem.

V prvních týdnech v Anglii byla rodina ubytovaná v domě pro azylanty, kde dostávali snídani a večeři. To, že zcela hypoteticky by hlady nezemřeli, posiluje domněnku o tom, že jídlo neznamená jen uspokojení fyziologických potřeb; jíst podle svých představ je součástí samozrrejmého, existenčně bezpečného světa (Szczepaniková 2004: 6). Překážkou snaze jíst podle svých představ však nemusí být pouze pečující internace v azylové ubytovně, proti znovu-vybudování samozrrejmého světa stojí ,jiná společnost“", ve které v obchodě najdete jiný sortiment a ten, který znáte, zde naopak není, nebo je popsán nesrozumitelným jazykem:

MB: Už byly čtyři hodiny, ted' já co koupím, tak jsem koupila takové hranolky předsmažené, a to druhé jsem myslela, že jsou takové placky z masa...

KB: Brambory.

MB: ... a to byly taky brambory. Tak děcka měly hlad, tak to snědly. [Paní Balunová se dojme a trošku pláče.] První jídlo, co jsem děckám udělala, byly brambory s bramborama, no strašné.

Často jsou také zmiňovány cigarety a káva. Podle některých výzkumů, i mé vlastní zkušenosti z některých návštěv v domácnostech českých Romů, kteří mají zkušenost migrace, jsou cigarety jednou z prioritních komodit spotřeby v domácnostech s nízkým př́ímem a konzumují je srovnatelně muži i ženy (Morris 1996: 478). Pan a paní Balunovi kouři každý jiné cigarety a podobnou zkušenost jsem měla i v jiné rodině během výzkumu. ${ }^{17}$ Důležitost cigaret je ve vyhrocené situaci těsně po př́jezdu do Anglie stavěna vedle jídla.

MB: [...] dva dny jsme nejedli, cigarety jsem neměla, to byla katastrofa.

MB: Ted’ jsme byli bez peněz, bála jsem se, dovolili mi, abych měla karton cigaret, ale ten byl pryč za tři dny, kouřila jsem jednu za druhou, ted’ děcka měly hlad, měli jsme nějaké zásoby, staré jídlo jsem jim nemohla dát, děcka dostaly dva tousty s vajičkem, večeře, koupila jsem v nejdražším obchodě chleba, máslo, sýry, dva litry sodovky, [...] museli jsme mít sociálku, byli jsme bez peněz. V automatu jsme koupili teplou čokoládu a tak, když přišel manžel, tak dovezl salám a chleba.

KB: Tys byla lakomá na kávu. 
Káva je další spotřební komoditou, která hraje v životě a vyprávění Balunových velkou roli. S panem Baluno jsme se shodli, že jeho manželka vaří velmi silnou kávu. Paní Balunová zmiňovala kávu v souvislosti s tím, že v Anglii měla najednou kávy neočekávaný nedostatek, a tak se vyjevila její důležitost.

Důležitost kávy a cigaret stoupla ve stresové situaci přejezdu do Anglie, ${ }^{18}$ i když tyto komodity jsou nepochybně velmi důležité v každodenním životě Balunových i v České republice.

Krátce se ještě zmíním o roli automobilu v rodině Balunových.

Když jsem začala rodinu Balunovou navštěvovat, jezdil pan Baluno v pískově žluté Ladě. Později mi paní Balunová říkala, že Ladu už nemají a nyní si podle jejích slov s pomocí finanční podpory maminky pana Baluno koupili jiné auto, aby mohl pan Baluno jezdit za nemocným otcem do nemocnice. Nicméně auto nebylo koupeno s řádnou smlouvou a oni mají nyní problém s proplacením závady, která se vyjevila záhy po koupi. V Anglii měli Balunovi ke konci pobytu také auto.

\section{LB: [...] pak jsem měl golfa [VW Golf].}

Zdá se, že Balunovi jsou zvyklí automobil používat, mohou-li si to finančně dovolit, auto si pořídí. Zároveň nemají ani v Ústí nad Labem několik let jeden stejný automobil, zdá se spíše, že si auto prŕležitostně tu více, tu méně výhodně pořizují. Předpokládám, že auto obsluhuje pouze pan Baluno, paní Balunovou jsem neviděla ř́́dit a pan Baluno se také k autu majetnicky hlásil a tato pozice mu byla přisuzována manželkou v souvislosti s návštěvami otce $\mathrm{v}$ nemocnici.

\section{Vymístěná spotřeba - bez okázalosti}

Nemožnost hýřivé okázalé spotřeby nad rámec uspokojení základních životních potřeb je v každodennosti Balunů zcela zřejmá. V České republice je dána nedostatkem peněz „navíc“, v Anglii ji v prvních týdnech také znemožňoval nedostatek znalostí místního prostředí. To se však časem měnilo a Balunovi s povzdechem vzpomínají na návštěvy KFC, McDonald's a kolotočů. Pozoruhodné v tomto směru je, že Balunovi nespojují hýřivou spotřebu se zásluhovostí, na kolotoče není myslitelné chodit jen tehdy, je-li člověk zaměstnán, jde o to, má-li na ně dost peněz, byt' by měly pocházet $\mathrm{z}$ podpory $\mathrm{v}$ nezaměstnanosti. To jde proti administrativní logice (a snad i etice) státní podpory v nezaměstnanosti, ale nikoliv proti logice subjektivní povahy životních potřeb, zvláště v pozdně moderní době, kdy konzumovat znamená být společensky naživu. Pro paní Balunovou zřejmě není základní životní potřebou jít na oběd do KFC, ale dát svým dětem to nejlepší a pokud možno vše, co si ony samy pro št’astný život přejí. Pokud to nejde, pocituje nedostatečnost a ve svém společenském zrcadle může nenacházet svůj obraz dobré matky svých dětí, a to je z hlediska vymístění důležité bez ohledu na to, co tento stav zaprííciňuje. 


\section{Závěr - vymístění jako znemožnění i možnost}

Z předchozích pasáží by mohl vzniknout dojem, že vymístěním rozumím existenci nenaplněných životních představ a snů. Takové sny a představy má snad každý moderní člověk nebo se to od něj přinejmenším očekává. Mají být motorem pohánějícím jedince na cestě k jejich uskutečnění. Vymístění však znamená nemožnost, respektive pocit nemožnosti se těmto snům a představám s pomocí vlastní vůle a píle přibližovat. Když se pan Baluno nechá načerno zaměstnat jako závozník, protože jinou práci se mu nedaří získat, svým snům a představám se může naopak ještě vzdálit, bude-li přistižen. Koupí auto, ale není smluvně chráněn před závadami v záruce, a tak prodělá. Jeho snahy se zkrátka míjí účinkem, což vyvolává pocity zoufalství a bezmoci i u jeho manželky.

Zoufalství a bezmoc provázely také vyprávění o pobytu v Anglii. V něm však bylo obsaženo ještě něco - naděje. Onen výhled do světlé budoucnosti, která se nemusí naplnit, ale je možné k ní směřovat. Rodná kultura totiž neobsahuje jen normativy životního stylu, ale také normativy životního směřování - co je možné si prát a jak je nutné postupovat na cestě ke splnění prání.

Pan Baluno hledí do budoucna s nadějí - bude jezdit pracovat do Anglie. Nicméně, jak moc je jeho úsudek o úspěšnosti takové strategie realistický, když v Anglii pracoval pouhý týden? Jedna z věcí, kterou si paní Balunová pochvalovala na práci v Anglii, byla, přeneseně řečeno, volná pracovní doba. A pocit, že práci by měli pořád. Tady v současné době práci již dlouho nemají, a když začal pan Baluno pracovat na černo, okamžitě se mu to vymstilo. Pobyt v České republice ho k plánům do budoucna neinspiruje. Balunovi tak žijí ve dvojí, paralelní budoucnosti, každá z nich má svá lákadla. Do Anglii je zaměřena naděje existenčního zabezpečení, $v$ České republice je to život $\mathrm{v}$ jistotě známých míst a srozumitelného jazykového a kulturního prostředí. Tyto budoucnosti nemusí být ve vzájemném napětí, mohou se v představách harmonicky doplňovat, ale která z možností se nakonec uskuteční, to nám vyprávění manželů Balunových nepoodhalila.

Navzdory dynamice a aktivnosti, která je v aktu vycestování a návratu Balunových obsažena, můžeme pozorovat, jak se s nimi do Anglie a zpátky jako další př́íbuzný stěhovala také pozice na okraji společnosti. Zdá se, že síla habitu, v př́padě Romů efektivně zkombinovaná se společenskými předsudky, Balunovy spolehlivě upoutává do pozice na okraji společnosti, z níž by se snad hypoteticky mohli vymanit, kdyby změnili nejen zemi, ale také kulturně-společenský okruh, v němž jsou zakotveni. ${ }^{19} \mathrm{~V}$ praxi jim však ted' a tady mnoho možností sociálního vzestupu nezbývá.

Je zde ale ještě jedna možnost, jistě optimističtější a snad neméně blízká popisu reálného stavu věcí. Možná, že Balunovi prostě tvưrčím způsobem (v mezích své vlastní imaginace, jako všichni sociální aktérii) uskutečňují své životní projekty podle představ, které nemusí nutně korespondovat s dominantními kulturními formami, což však neznamená, že nemohou pro konkrétní aktéry „fungovat“. Jak píše Pile (Pile 1997: 2-3), lidé nacházející se v nerovné společenské struktuře $\mathrm{v}$ nižších patrech prostě jen vytvářejí světy odlišné od těch, které jsou definovány těmi nahoře, prostory, kde dominace a odpor ztrácí svůj jednoznačný význam. Takto položený závěr je ovšem neméně křehký. Svádí k prohlášení, že všichni jsou ve svých pozicích vlastně štastni, a to, jak jsme viděli u Balunů, rozhodně neplatí.

Připomeňme si ještě jednou koncept kvality života a zmínky o životních preferencích Balunových. Objeví se obraz, který s pomocí obou předchozích perspektiv vykresluje ještě 
jinou, možná ne tak optimistickou, ale ani zcela pesimistickou variantu. Zdá se, že Balunovi se s pomocí odchodu do Anglie snažili vylepšit svou životní situaci, což se jim částečně podařilo, a že tak činili a činí v mezích vlastních životních zvyklostí a imaginace. Jejich vykořeněná kulturní identita se jim tak v každém okamžiku stává možnou platformou otřesu také těch podmínek, a zvyklostí, které je, laicky řečeno, udržují u dna. Pan Baluno jednou možná pocítí i v České republice spontánní potřebu začít se sám učit anglicky, jako ji podle jeho slov pocítil po prvních dnech v Londýně, a také se učit začal. Myslím, že kdyby se to stalo, mohlo by to indikovat, že doba hrubé kulturní vykořeněnosti českých Romů pomalu pomíjí. Do té doby budou asi někteří za pozitivními otřesy odjíždět do zahraničí, kde budou podstupovat dramata prvních dnů a týdnů v cizině, dramata, jež se však pomalu blíží těm, která mnozí čeští Romové zakoušejí v boji o důstojnou materiální a společenskou existenci zde v České republice.

\section{Poznámky}

1 Pojmy „cílová“ a „domovská“ země jsou stejně jako pojem „migrace“ užívanému slovníku těch, kterých se v tomto konkrétním výzkumu týkají, poměrně vzdálené. Výzkum, na kterém je postavena tato stat', však není paradigmaticky zakotven v metodách protěžujících emic (Lett 1990) významy. Mou snahou je spíše uskutečnit s tak zvanými aktéry z pozice sociálního vědce oboustranně důstojný a pro čtenáře sdělný dialog.

2 Romština se zhruba ze 60 \% shoduje s hindštinou a má několik více či méně odlišných variant. Jednou z nich je např́íklad slovenská romština a její dialekty, kterou hovoří převážná většina Romů žijících na území České republiky.

3 Navzdory tomu, že pozice ,plnohodnotného člena společnosti““ je ze sociologické perspektivy pozicí analytickou, a tedy ve své čisté formě v žité realitě nedosažitelnou, je důležité, že pro některé Romy, kteří odešli, či o odchodu uvažují, může být v jejich představách reálnou.

$4 \quad$ To se v české společnosti netýká jen Romů. Jak poznamenává Gabal (Gabal a kol. 1999), česká společnost je vysoce xenofobní. Je ovšem nutno číst podobné výzkumy kriticky; domnívám se, že riziko optického klamu, kdy fenomén je nalezen, protože ho patřičné nástroje pomáhají vytvářet, je v oblasti mezi-etnických společenských vztahů vysoké.

5 Adresnost není žádaná ani na straně účastníků výzkumu, ani na zkoumající straně, proto jsem změnila jména účastníků výzkumu a také některé biografické detaily, které jsou z hlediska sledovaného tématu nevýznamné. Veškeré citace jsou ve skutečnosti přepsanými parafrázemi. Výzkum je realizován převážně bez diktafonu, autorka si v terénu pořizuje stručné poznámky, prrípadně zpracovává veškeré písemné zápisy z pozorování a konverzací až zpětně.

6 Konkrétně jsou to Monika a Lubomír Balunovi (v textu iniciály MB a LB), nejstarší Karolína Balunová $(\mathrm{KB})$ a další děti Teodor, Věrka a Aneta, které zde přímo nepromlouvají. Autorka v textu figuruje pod vlastními iniciály (KJ).

7 Samozřejmě jsem mohla více naléhat na vysvětlení této fáze „migrace“, záměrem výzkumu však také bylo ponechat co nejvíce přirozenou strukturu významnosti a „zveřejnitelnosti“ informací o „migraci“ tak, jak jí rozumí samotní její aktéři (Emerson, Fretz a Shaw 1995: 11). Zaměřenost na porozumění v kontextu struktury významů a žité každodennosti je přirozeným limitem, ale také potenciálem etnografického výzkumu v sociologii.

8 „V každém okamžiku každé společnosti máme prostě co činit s určitým celkem sociálních pozic, který je homologicky spjatý s určitým celkem aktivit (pěstování golfu nebo hry na klavír) a statků (sídlo na venkově nebo obraz mistra), jež samy jsou rovněž charakterizovány vztahově“ (Bourdieu 1998: 13). 
9 V tomto kontextu především bezprostředně pozorovatelné kvality.

10 To, že v postindustriálních společnostech přibývá lidí pracujících takzvaně „doma“, je znakem proměny prostoru pracoviště, ale také soukromí. Možný (v referenci na Beckovu úvahu, kterou Beck rozvádí nad paradoxem individualizace ve své knize Risk Society (1986); jedinci jsou zde podle Becka společenským vývojem manipulováni k individualizaci, ale zároveň se stávají více a více existenčně závislými na sfére pracovního trhu) poznamenává: „Vypadá to opět na revoluci, tentokráte revoluci světa soukromého, nikoli veřejných struktur“ (Možný 1999: 204).

11 Sibley také mluví o tom, že stereotyp místa odpovídá určitému stereotypu skupiny. Na dualitě domov-pracoviště je to patrné ve dvou extrémech prezentace práce a ne-práce, v prrípadě workoholiků (jsou prŕíliš mnoho v práci a tudíž nejsou uznáni za schopné prožívání soukromého života), respektive Romů (nechodí do práce, tudíž nesdílí společenskou normu chování, která se v zaměstnání reprodukuje). Jedinec, který má představovat zástupce určité sociální skupiny, tak bude např́íklad v mediálním sdělení představen spíše v prostředí, které podtrhuje stereotypní představy o skupině (workoholici v kanceláři, Romové na ulici). Prostor je tak podle Sibleyho jak znemožňující, tak umožňující médium. Workoholik se zdá být workoholikem právě proto, že je v práci, přesto, že určitou část dne musí zákonitě trávit i jinde, a podobně.

12 Hranaté závorky vyznačují doplňující a vysvětlující komentáře autorky výzkumu v přepisech. Pokud jsou v hranatých závorkách tři tečky, poukazují na pasáž vynechanou z vyprávění.

13 Rodina (podle vyjádření paní Balunové usuzuji, že zvláště její tchýně) Balunovy finančně podporovala nejen v období jejich snah odjet a usadit se v Anglii, ale podporuje je také v současnosti.

14 Poměrně skromné výpovědi v této oblasti mohou také souviset se záměrnou neřízeností rozhovorů a jejich tématickou orientací na zkušenost migrace.

15 Balunovi měli hned vedle v domě anglické sousedy, kteří je zaměstnali.

16 Opakovaná migrace je pozorovaná jako jev typický pro novodobou „romskou migraci“ (ne však výlučně tuto migraci charakterizující) (Gabal 2000).

17 To je možná u silně kuřáckých párů běžné, nemám takovou osobní zkušenost, proto mě to překvapilo.

18 Samozřejmě i v České republice zažívají Balunovi stresové situace, pokus o migraci však považuji za biograficky mimořádně výlučný a stresující moment (Schütze a Riemann 1990).

19 Jak Česká republika, tak Anglie jsou tržně-demokratické země s větší či menší mírou kulturní hegemonie bílého středostavovského muže.

\section{Literatura}

Bammer, A. 1994. „Introduction.“ In A. Bammer (ed.) Displacements. Cultural Identities in Question. Bloomington and Indianapolis: Indiana University Press.

Beck, U. 1986. Risk Society. London: Sage.

Berger, P. L., Luckmann, T. 1999. Sociální konstrukce reality. Pojednání o sociologii vědění. Brno: CDK.

Bourdieu, P. 1998. Teorie jednání. Praha: Karolinum.

Emerson, M. R., Fretz, I. R., Shaw, L. L. 1995. Writting Ethnographic Fieldnotes. Chicago, London: The University of Chicago Press.

Gabal Analysis \& Consulting. Květen 2000. Analýza migračního klimatu a migračních tendencí do západoevropských zemí v romských komunitách ve vybraných městech $\breve{C}$. (Výzkumná zpráva) pro IOM Prague. Praha: Gabal Analysis \& Consulting. 
Gabal, I. a kol. 1999. Etnické menšiny ve střední Evropě: konflikt nebo integrace. Praha: GplusG.

Giddens, A. 1998. Di̊sledky modernity. Praha: Slon.

Janků, K. 2001. „Emigrace z České republiky do Kanady v období uvolnění vízové povinnosti od 1. dubna 1996 do 7. ř́ína 1997 a její institucionální dopady.“ Mezinárodní otázky 2/X.

Krchovský, J. H. 1998. Básně. Brno: Host. (Uvedená báseň pochází ze sbírky Mé lebky stín [1989-1991].)

Lett, J. 1990. „Emics and Etics. Notes on the Epistemology of Anthropology.“ In T. Headland, K. Pike, M. Harris (eds.) Emics and Etics. The Insider/Outsider Debate. London: Sage.

Morris, L. 1996. „Researching Living Standards: Some Problems and Some Findings.“ Journal of Social Policy, 25/4.

Pile, S. 1997. „Introduction. Opposition, political identities and spaces of resistance.“ In S. Pile, M. Keith (eds.) Geographies of Resistance. London: Routledge.

Schütze, F., Riemann, G. 1990. „Trajectory as a basic theoretical concept for analyzing suffering and disorderly social processes.“ In D. Maines, D. (ed.) Social Organization and Social Processes. Hawthorne: Aldine.

Siebley, D. 1997. Geographies of Exclusion. London: Routledge.

Slater, D. 1997. Consumer Culture and Modernity. Cambridge: Polity.

Szalai, A. 1980. „The Meaning of Comparative Research on the Quality of Life.“ In A. Szalai, F. M. Andrews (eds.) The Quality of Life. Comparative Studies. London: Sage.

Szepaniková, A. 2004. „V moci uprchlických táborů: pohled na českou ,uprchlickou realitu“.“ Portál Migraceonline [online, cit. 1. 8. 2004]. Dostupné z: http://www.migraceonline.cz/ index.shtml

\section{Autorka}

Kateřina Janků je doktorandkou na katedře sociologie FSS MU v Brně a odbornou asistentkou na Katedře sociální geografie a regionálního rozvoje PřF OU v Ostravě. V současné době se zabývá fenoménem migrace českých Romů na Západ po roce 1989, který zpracovává metodami etnografické sociologie. Kontaktní e-mail: jankuu@fss.muni.cz 